\title{
Surgarcane biopolymer patch in femoral artery angioplasty on $\operatorname{dogs}^{1}$.
}

\author{
Membrana de biopolímero de cana-de-açúcar como remendo em \\ arterioplastias femorais de cães.
}

\author{
José Lamartine de Andrade Aguiar², Esdras Marques Lins ${ }^{3}$, Silvio Romero de Barros Marques ${ }^{4}$, Antônio Roberto de \\ Barros Coelho ${ }^{2}$, Renata de Oliveira Rossiter ${ }^{5}$, Roberto José Vieira de Melo ${ }^{6}$ \\ 1. Research performed at Experimental Surgical Research Laboratory (NCE), Federal University of Pernambuco (UFPE). Recife, Brazil. \\ 2. PhD, Associate Professor, Department of Surgery, UFPE, Brazil. \\ 3. PhD, Full Professor of Vascular Surgery, Department of Surgery, , UFPE, Brazil. \\ 4. Assistant Professor, Department of Surgery, UFPE, Brazil. \\ 5. Resident of Pathology, Clinical Hospital, UFPE, Brazil \\ 6. PhD Associate Professor, Department of Pathology, UFPE, Brazil
}

\begin{abstract}
Purpose: The objective of this study was to evaluate the use of the sugarcane biopolymer membrane in femoral artery patch angioplasty on dogs. Methods: Eight dogs were submitted to bilateral femoral artery patch angioplasty with a sugarcane biopolymer membrane patch on one side and e-PTFE patch on the contralateral side. This research was performed at Experimental Surgical Research Laboratory of the Centro de Ciências da Saúde at Universidade Federal de Pernambuco. The dogs were submitted to a new surgery at 180 days after the patch angioplasty in order to harvest the femoral artery. All the animals were evaluated by: clinical examination, measure of femoral artery diameter, arteriogram and Doppler fluxometry. Yet the material harvested was sent to histological study. Each animal served as its own control. Results: In all vessels of both groups there were no cases of infection, aneurysm formation, rupture or pseudoaneurysm formation and thrombosis. In both groups it was observed a chronic inflammatory reaction with lymphocytes, neutrophils and fibrosis in the outer surface of the patches. It was observed fibrosis in the inner surfaces of all the patches. In e-PTFE patches occurred invasion by fibroblasts. Conclusion: The sugarcane biopolymer membrane can be used as a patch in femoral artery angioplasty on dogs.
\end{abstract}

Key words: Blood vessel prosthesis. Blood vessel prosthesis implantation. Bioprosthesis. Sugarcane

\section{RESUMO}

Objetivo: Avaliar a utilização da membrana do biopolímero de cana-de-açúcar quando utilizada como remendo em arterioplastias femorais de cães. Métodos: Oito cães foram submetidos a arterioplastia femoral bilateral com enxertos em remendo com a membrana do biopolímero de cana-de-açúcar em um lado e com a prótese de e-PTFE no lado contra-lateral. Os experimentos foram realizados no Núcleo de Cirurgia Experimental do Centro de Ciências da Saúde da Universidade Federal de Pernambuco. A avaliação dos animais foi realizada através do exame clínico, da medida do diâmetro das artérias femorais, da fluxometria Doppler, da arteriografia e da histologia. Após 180 dias os cães foram submetidos a nova cirurgia para retirada dos segmentos das artérias femorais com os implantes. Resultados: No período de avaliação nos dois grupos, não se observou casos de infecção, dilatação, ruptura ou falso-aneurisma e trombose. Nos dois grupos foi encontrada uma resposta inflamatória crônica com neutrófilos, linfócitos e fibrose na superfície externa dos remendos. Foi observada também a presença de fibrose na superfície interna em ambos os grupos. No grupo controle ocorreu invasão dos remendos de e-PTFE por fibroblastos. Conclusão: A membrana do biopolímero de cana-de-açúcar pode ser utilizada como remendo em arterioplastias femorais de cães.

Descritores: Prótese vascular. Implante de prótese vascular. Bioprótese. Cana-de-açúcar 


\section{Introduction}

Although the technological development that permitted the production of better arterial substitutes, the search for an ideal material still continues, especially to use it in small arteries. The perfect substitute has to present the right technical properties for its application in humans besides a low cost of production to allow its wide utilization ${ }^{1,2}$. Several researches have evaluated the use of new materials to the substitution of blood vessels. These studies have showed the advantages of them compared to the traditional arterial substitutes ${ }^{1,3}$. A special group of material has been studied. They are produced from many species of microorganisms and showed similar characteristics to human tissues, as elastic properties and resistance to rupture. Among these microorganisms, there are some types of bacterial which have the ability to synthesize polysaccharides and excrete them out of the cell as soluble or non soluble polymers, which have been used in several areas of the medical research 3-12. An extracelular polysaccharide was produced through microbiology synthesis at Industrial Microbiological Laboratory of the Sugarcane Experimental Station at Carpina / Universidade Federal Rural de Pernambuco and purified for biological use at Experimental Surgical Research Laboratory (NCE) / Universidade Federal de Pernambuco ${ }^{13,14}$. This polysaccharide was produced from sugarcane molasses and was named sugarcane biopolymer. The membrane obtained from this biopolymer was evaluated trough laboratorial tests and showed high biocompatibility besides low cytotoxicity ${ }^{\mathbf{1 4}}$. The sugarcane biopolymer membrane is easily synthesized with a low cost of production. This membrane has been used in many areas of experimental surgery as in the healing of skin wounds, in the urinary reconstruction and in the reconstruction of tympanic membrane, but there is no report of its use as arterial substitute ${ }^{\mathbf{1 5}-\mathbf{1 7}}$. In order to evaluate the possibility of using the sugarcane biopolymer membrane in arterial reconstructive surgery, this study analyze its utilization in femoral artery patch angioplasty.

\section{Methods}

Eight adult dogs (Canis familiaris) weighing on average 15,44 Kg, divided into 7 males and 1 female, were used in this study. The animals were housed in the biotery for a 21-day period before the surgery was carried out. They were fed with commercial dog feed, vaccinated against rabies (hydrophobia) and received a dose of vermicide. A 24-hour period of fasting from solid feed was observed for all dogs before the operation was done. The dogs were anesthetized intravenously with sodium thiopental (dosage 12,5 / Kg), pancuronium bromide (dosage 0,2 $\mathrm{mg} / \mathrm{Kg}$ ) and ketamine hydrochloride (dosage $2,5 \mathrm{mg} / \mathrm{Kg}$ ), intubated, and so the bilateral femoral Doppler fluxometry was performed. After, the femoral region were prepared and draped in sterile fashion. The access to the left and right femoral arteries was made via 5-centimeter longitudinal incision on the skin and subcutaneous tissue and the macroscopic measure of femoral artery diameter was taken. Femoral artery patch angioplasty was done by sewing a $1,5 \times 0,5 \mathrm{~cm}$ sugarcane biopolymer patch on the left side and the e-PTFE on the right side with a continuous 7-0 polyprolene suture (Figure 1). After recovering from anesthesia, the dogs were isolated in cages inside the biotery and were feed within 8 hours after having undergone surgery. They were submitted to daily clinical evaluation for the first week and then weekly thereafter. End point for vessel harvest was 6 months. All the animals were submitted to a new surgery after 6 months observing the same conditions of anesthesia and access as those used for the first surgery. The abdominal region was also prepared and draped en sterile fashion. The femoral arteries were exposed, and gross evaluation was performed. Doppler fluxometry and the macroscopic measure of the diameter of the femoral arteries were performed and after an abdominal longitudinal incision was made to expose the aorta for arteriographic access, and bi-planar arteriography was taken. After the arteriograms were obtained each femoral artery was harvested and sent to the Histopathology Laboratory at Hospital das Clínicas at Universidade Federal de Pernambuco. After that all the animals were killed. All the experiments were performed at Experimental Surgical Research Laboratory of the Centro de Ciências da Saúde at Universidade Federal de Pernambuco from January 2005 to December 2006. The experiments were divided in two groups: Experimental group with 08 sugar cane biopolymer membrane patches and control group with 08 e-PTFE patches. Each animal served its own control.

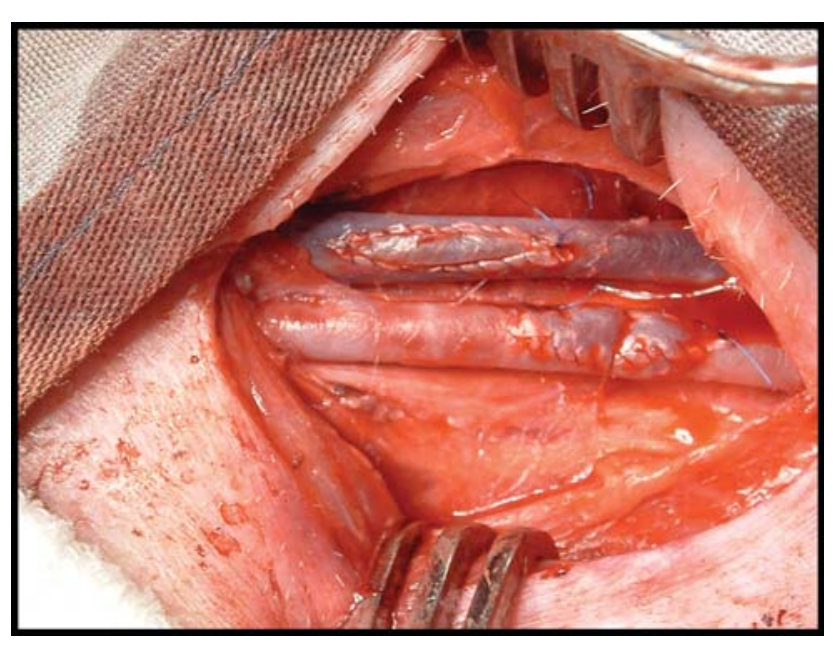

FIGURE 1 - femoral artery patch angioplasty using sugar cane biopolymer membrane. In the same figure it is possible to see the femoral vein with the sugarcane biopolymer patch.

\section{Results}

All the animals survived to the period of 180 days to clinical observation. There were no cases of infection, aneurysm formation, rupture or pseudoaneurysm formation and thrombosis in both groups (Figure 2). There were no statistical differences in the femoral artery diameter before and 180 days after angioplasty ( $p>0,05$ by using Wilcoxon Test) (Table 1). In both groups it was observed a chronic inflammatory reaction with 
lymphocytes, neutrophils and fibrosis in the outer surface of the patches. It was observed fibrosis in the inner surfaces of all the patches. The new intimal an adventicial layers were firmly bound to the surfaces of the patches (Figure 3). In both groups there were no cases of degenerative process and calcification. In e-PTFE patches occurred invasion by fibroblasts (Figure 4).

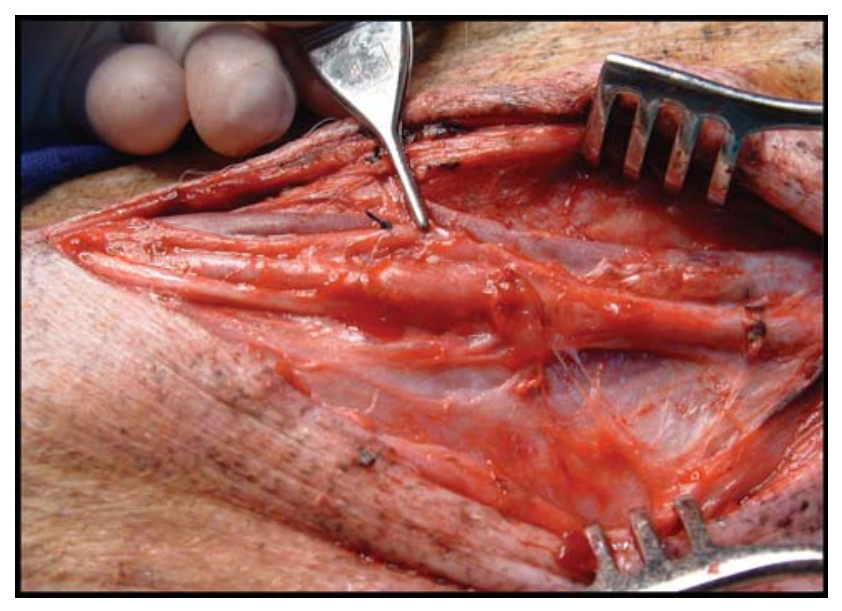

FIGURE 2 - Femoral artery with sugarcane biopolimer membrane patch after 180 days.

TABLE 1 - Femoral artery diameter before and after the angioplasty, according to the used material.

\begin{tabular}{|c|c|c|c|c|}
\hline \multirow[b]{2}{*}{ Variables } & \multicolumn{4}{|c|}{ Material } \\
\hline & Statistics & $\begin{array}{l}\text { Experimental } \\
\qquad(\mathrm{n}=8)\end{array}$ & $\begin{array}{l}\text { PTFE } \\
(\mathrm{n}=8)\end{array}$ & $\mathrm{p}$ \\
\hline \multirow{6}{*}{$\begin{array}{l}\text { - Femoral artery diametrer before } \\
\text { angioplasty }\end{array}$} & Arithmetic mean $^{(1)}$ & 0,375 & 0,394 & \multirow[t]{6}{*}{$\mathrm{p}^{(2)}=0,180$} \\
\hline & Median ${ }^{(1)}$ & 0,375 & 0,375 & \\
\hline & Standard error ${ }^{(1)}$ & 0,046 & 0,073 & \\
\hline & C.V (\%) & 12,344 & 18,511 & \\
\hline & Minimum $^{(1)}$ & 0,300 & 0,300 & \\
\hline & Maximum ${ }^{(1)}$ & 0,450 & 0,500 & \\
\hline \multirow{6}{*}{$\begin{array}{l}\text { - Femoral artery diametrer after } \\
\text { angioplasty }\end{array}$} & Arithmetic mean ${ }^{(1)}$ & 0,381 & 0,394 & \multirow[t]{6}{*}{$\mathrm{p}^{(2)}=0,157$} \\
\hline & Median ${ }^{(1)}$ & 0,400 & 0,400 & \\
\hline & Standard error ${ }^{(1)}$ & 0,037 & 0,050 & \\
\hline & C.V $(\%)$ & 9,758 & 12,585 & \\
\hline & Minimum $^{(1)}$ & 0,300 & 0,300 & \\
\hline & Maximum $^{(1)}$ & 0,400 & 0,450 & \\
\hline \multirow[t]{6}{*}{ - Variation ( after - before ) } & Arithmetic mean ${ }^{(1)}$ & 0,006 & 0,000 & \multirow[t]{6}{*}{$\mathrm{p}^{(2)}=0,317$} \\
\hline & Median ${ }^{(1)}$ & 0,000 & 0,000 & \\
\hline & Standard error ${ }^{(1)}$ & 0,032 & 0,038 & \\
\hline & C.V $(\%)$ & & & \\
\hline & Minimum $^{(1)}$ & $-0,050$ & $-0,050$ & \\
\hline & Maximum ${ }^{(1)}$ & 0,050 & 0,050 & \\
\hline $\mathrm{p}$ & & $\mathrm{p}^{(2)}=0,564$ & $\mathrm{p}^{(2)}=1,000$ & \\
\hline
\end{tabular}

(1) - Measure in cm.

(2) -Wilcoxon test.

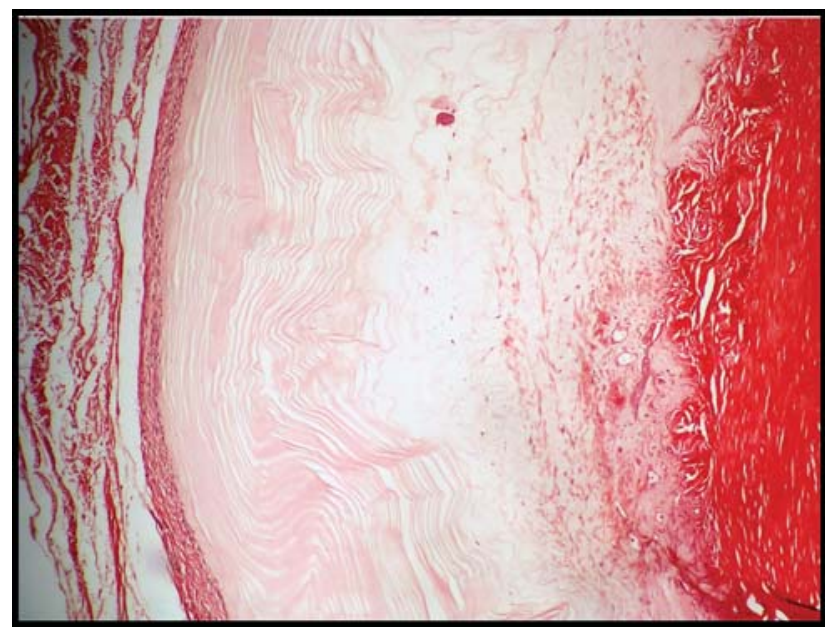

FIGURE 3 - Chronic inflammatory reaction in the outer surface and fibrosis in the inner surface of the sugarcane membrane patch.

-Wilcoxon test. 


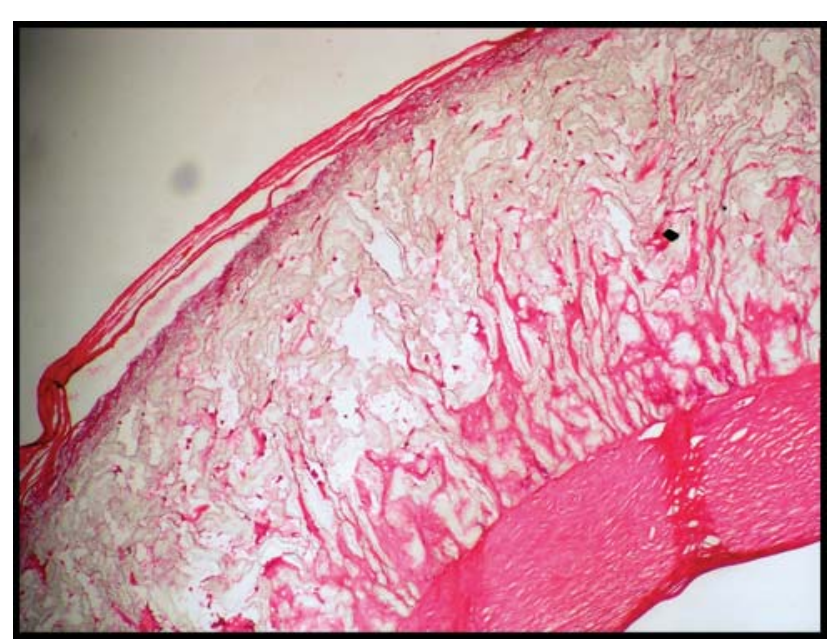

FIGURE 4 - Invasion of e-PTFE patch by fibroblasts and chronic inflammatory reaction in the outer surface. Fibrosis in the inner surface.

\section{Discussion}

The concept of the patch angioplasty was first established by Carrel, in 1906, but this surgical technique was only widely used after the reports of Senning and Crawford et al, in 1959, which in different studies showed that the use of a patch could avoid the stenosis after an arteriotomy ${ }^{\mathbf{1 8 - 2 0}}$. The majors complications with the use of the patches are similar to those of the other kind of arterial substitutes; they are: thrombosis, rupture or pseudoaneurysm formation, operatory wound infection, and aneurysm formation. These complications have been reported in the literature. The time of clinical observation in the experimental studies using patches has been variable ${ }^{21-27}$. In the present study there were no complications. The results were confirmed through clinical evaluation, Doppler fluxometry, angiography and the macroscopic measure of femoral artery diameter. These results are not uncommon and have been showed in other experimental studies ${ }^{26,27}$. The high rate of complications of the earlier experimental studies with patches were most likely, consequence of the use of inappropriate materials in artery anastomosis. Those complications can occur also due to the failure of the material used, as was observed by McCready et al, in 2005. They showed the high rate of pseudoaneurysm formation with the utilization of small intestinal submucosa patches in carotid angioplasties ${ }^{21-25,28}$. The healing process of an arterial substitute is a consequence of the reactions that occur among its wall and the organic tissues which are related with it. The healing process is considered good when this tissues invade the patch or bind firmly to it ${ }^{29-31}$. The present study showed the presence of a chronic inflammatory reaction in the outer surface of the sugarcane biopolymer patches and fibrosis in the both surfaces. There were no cases of degenerative process, with destruction of the integrity of the patches as occur with autologous substitutes. This inflammatory reaction and the fibrosis also occur with the synthetic prosthesis, including the e-PTFE ${ }^{21-23,25,26,29,30,32,33}$. The rare presence of macrophages in the both groups confirms the low antigenic capacity of the two material used. Also in a way similar to synthetic prosthesis there were no cases of calcification ${ }^{29,30,32,33}$. In a different way of synthetic prosthesis, the sugarcane biopolymer patches did not permitted the invasion by fibroblasts. The invasion observed in the e-PTFE patches has been described in the literature and occurred because they present microporous which allow the cellular migration. The sugar cane biopolymer patches do not have porous and so did not permitted the invasion, but the new layers were firmly bound to them. This behavior is similar to the healing process of the biological prosthesis, as the human umbilicus cord vein, that also do not permit the cellular migration ${ }^{29,30,33-35}$.

\section{Conclusion}

The sugarcane biopolymer membrane patch can be used in femoral artery angioplasty on dogs.

\section{References}

1. Xue L, Greisler HP. Biomaterials in the development and future of vascular grafts. J Vasc Surg. 2003; 37: 472-80.

2. Leon L, Greisler HP. Vascular grafts. Expert Rev Cardiovasc Ther. 2003; 4: 581-94.

3. Klemm D, Schumann D, Udhardt U, Marsch S. Bacterial synthesised cellulose - artificial blood vessels for microsurgery. Prog Polym Sci. 2001; 26: 1561-603.

4. Cavalcante AHM, Carvalho LB, Carneiro-da-Cunha MG. Cellulosic exopolysaccharide produced by Zoogloea sp. As a film support for trypsin immobilization. Biochem Eng J. 2006; 4203: 1-4.

5. Ewald E, Malafaia A, Matias JEF. Celulose liofilizada para fechamento do retroperitôneo em ratos. Arq Bras Cir Dig. 2001; 14: 129-32.

6. Nemetz AP, Loures DRR, Coelho JCU. Efeito estrutural da utilização de celulose biossintética e politetrafluoretileno expandido como substitutos do peritônio em cães. Arq Bras Cir Dig. 2001; 14: 139-42.

7. Sutherland IW. Microbial polysaccharides from Gramnegative bacteria. Int Dairy J. 2001; 11: 663-74.

8. Svensson A, Nicklasson E, Harrah T, Panilaitis B, Kaplan DL, Brittberg M, et al. Bacterial cellulose as a potential scaffold for tissue engineering of cartilage. Biomaterials. 2005; 26:419-31.

9. Entcheva E, Bien H, Yin L, Chung CY, Farrel M, Kostov Y. Functional cardiac cell constructs on cellulose-based scaffolding. Biomaterials. 2004; 25:5753-62.

10. Shuterland IW. Industrially useful microbial polysaccharides. Microbiol Sci. 1996; 3: 5-9.

11. Shuterland IW. Novel and established applications of microbial polysaccharides. Trends Biotechnol. 1998; 16: 41-6.

12. Lopes LMA, Andrade CT. Polímeros de origem microbiana: polissacarídeos bacterianos. Rev Química Industrial 1995; (703): 19-23. 
13. Peterson-Beedle M, Kenney JF, Melo FAD. A cellulosic exopolysaccharide produced from sugarcane molasses by Zoogloea sp. Carbohydrate Polymers. 2000; 42: 375-83.

14. Castro CMMB, Aguiar JLA, Melo FAD, Silva WTF, Marques E, Silva DB. Citotoxicidade de biopolímero de cana-de-açúcar. An Fac Med Univ Fed Pernambuco. 2004; 49: 119-23.

15. Coelho MCOC, Carrazoni PG, Monteiro VLC, Melo FAD, Mota RA, Tenório Filho F. Biopolímero produzido a partir da cana-de-açúcar para a cicatrização cutânea. Acta Cir Bras. 2002; 17(supl. 1): 11-3.

16. Chagas HM, Aguiar JLA, Andrade RT, Montoro M, Vilar FO, Lima SVC. Uso da membrana de biopolímero de cana-de-açúcar na reconstrução ureteral. Anais do $30^{\circ}$ Congresso Brasileiro de Urologia; 2005 Outubro; Brasília, BR. Rio de Janeiro : Sociedade Brasileira de Urologia ; 2005.

17. Silva DB, Aguiar JLA, Marques A, Coelho ARB, Rolim Filho EL. Meringoplastia com enxerto livre de membrana de biopolímero de cana-de-açúcar e fáscia autóloga em Chinchilla laniger. An Fac Med Univ Fed Pernambuco. 2006; 51:45-51.

18. Carrel A, Guthrie CC. Anastomosis of blood vessels by the patching method and transplantation of the kidney. J Am Med Assoc. 1906; 47: 1648-51.

19. Senning A. Strip-graft technique. Acta Chir Scand. 1959; 118: 81.

20. Crawford ES, Beall AC, Ellis Jr PR, De Bakey ME. A technique permitting operation upon small arteries. Surg Forum. 1959; 10: 671-5.

21. Rossi NP, Koepke JA, Spencer FC. Histologic changes in long-term arterial patchs grafts in coronary arteries. Surgery. 1965; 57: 335-42.

22. Wagner M, Ruel G, Teresi J, Kaiser K. The use of spandex as a vascular patch graft material. Surg Ginecol Obstet; 1968; 96: 805-7.

23. Menon SMR, Talwar JR, Roy S, Gopinath N. Comparison of Dacron velour and venous patch grafts for arterial reconstruction. Surgery. 1973; 73: 423-8.

24. Norton LW, Spencer FC. Long-term comparison of vein patch with direct suture. Technique of anastomosis of small arteries. Arch Surg. 1964; 89: 1083-8.

25. Pena LI, Husni EA. A comparative study of autogenous vein and Dacron patch grafts in the dog. Arch Surg. 1968; 96: 369-72.
26. Sarac TP, Carnevale K, Smedira N, Tanquilut E, Augustinos P, Patel A, et al. In vivo and mechanical properties of peritoneum / fascia as a novel arterial substitute. J Vasc Surg. 2005;41: 490-7.

27. Thomazine JÁ, Freitas MAS, Lachat JJ, Coutinho Neto J, Cherri J. Structural and ultrastructural study of the luminal surface of femoral arteries of dogs submitted at arterioplasty with implants of prosthesis manufactured from natural latex of Havea Brasilienses. Acta Microsc. 2001; 2: 263-4.

28. McCready RA, Hodde J, Irwin RJ, Coffey AC, Divelbiss JL, Bryant MA, et al. Pseudanerysm formation in a subset of patients with small intestinal submucosa biologic patches after carotid endarterectomy. J Vasc Surg. 2005; 41: 782-8.

29. Chakfé N, Dieval F, Thaveau F, Rinckenbach S, Hassani O, Camelot G, et al. Substituts vasculaires. EMC, Techniques chirurgicales - Chir. Vasc. 2003; 43-008: 1-12.

30. Sauvage LR. Comportamento biológico dos enxertos no sistema arterial. In: Haimovici H, Ascer E, Hollier LH, Strandness Jr. E, Towne JB. Haimovici Cirurgia Vascular Princípios e Técnicas. $4^{\circ}$ ed. Rio de Janeiro: DiLivros; 1999.p.157-92.

31. Greca FH, Noronha L, Costa FDA, Souza Filho ZA, Soccol T, Feres AN, et al. Estudo comparativo da biocompatibilidade da submucosa intestinal porcina e pericárdio bovino como enxerto na veia cava de cães. Acta Cir Bras. 2005; 20: 317-22.

32. Benzel EC, McMilan R, Fowler MR, Landreneau MD, Kesterson L, Payne DL. Histological comparison of autogenous canine fascia lata, Gore-Tex, lyophilezewd human fascia lata, and autogenous canine vein for vascular patch graft material in a canine arteriotomy model. Neurosurgery. 1992; 31: 108-13.

33. Gonzalez J, Mafei FHA, Moura R. Próteses e Enxertos Vasculares. In: Mafei FHA, Lastória S, Yoshida WB, Rollo HA, editores. Doenças Vasculares Periféricas. $3^{\circ}$ ed. Rio de Janeiro: MEDSI; 2002. p. 789-800.

34. Teijeira J, Morais Y, Aguiar L. Comparation of processed bovine internal mammary arteries and autologos vein as arterial femoral substitutes in dogs: Blood compability and pathological characteristics. Can J Surg. 1989; 32: 180-7.

35. Bernades CHA, NigroAJT. Comparison between biological prosthesis constituted of autogenous superficial femoral vein or human umbilicus cord vein interposed between two femoral artery stumps: an experimental study in dogs. Acta Cir Bras. 1996; 11: 76-81.

\section{Correspondence:}

José Lamartine de Andrade Aguiar

Av. Beira Mar, 4220/1201

54420-020 - JABOATÃO-PE

e-mail: aguiar@terra.com.br
Conflict of interest: none Financial source: none 